\author{
ROBERT HUTERSKI* \\ Uniwersytet Mikołaja Kopernika w Toruniu
}

\title{
STOSUNEK MIĘDZYNARODOWEGO FUNDUSZU WALUTOWEGO DO KONCEPCJI ZRÓWNOWAŻONEGO ROZWOJU
}

Słowa kluczowe: Międzynarodowy Fundusz Walutowy, wzrost gospodarczy, zrównoważony rozwój.

Klasyfikacja JEL: F33, F63.

Abstrakt: Z dokonanego przeglądu aktualnych publikacji MFW w zakresie stosunku tej instytucji do koncepcji zrównoważonego rozwoju wynika, że MFW bardzo często odwołuje się do tej koncepcji, nadając jej jednak własny wydźwięk, sprzeczny z istotą i celem oryginalnego ujęcia. Z jednej strony, MFW gloryfikuje przyspieszanie wzrostu gospodarczego i popytowe stymulowanie koniunktury, z drugiej zaś - nie odnosi się do skutków wad współczesnego globalnego systemu pieniężnego dla zrównoważonego rozwoju, chociaż jest tego systemu aranżerem i strażnikiem, a może właśnie dlatego.

\section{ATtitude OF THE InTERnATIONAL MONETARY Fund TO A CONCEPT OF SUSTAINABLE DEVELOPMENT}

Keywords: International Monetary Fund, sustainable development, economic growth. JEL Classification: F33, F63.

Abstract: Review of the IMF current publications from point of view of its attitude to idea of sustainable development shows that the IMF refers very often to this concept, but gives it specific meaning that is in contradiction with the essence and objective of the idea. On one hand, the IMF glorifies acceleration of economic growth. On the other,

Data wpłynięcia: 22.11.2012; data zaakceptowania: 25.02.2013.

* Dane kontaktowe: robhuski@uni.torun.pl, Katedra Zarządzania Finansami, Wydział Nauk Ekonomicznych i Zarządzania, Uniwersytet Mikołaja Kopernika, ul. Gagarina 13a, 87-100 Toruń, tel. 566114895. 
the IMF do not ponder effects of weaknesses of contemporary global monetary system for sustainable development, although that institution arranges and protects it.

Translated by Robert Huterski

\section{II WSTĘP}

Działalność gospodarcza człowieka wywiera coraz silniejszy negatywny wpływ na środowisko naturalne. Zakres i formy tej działalności zależą w dużym stopniu od zasad jej finansowania. Ponieważ współcześnie państwa coraz częściej stają się uzależnione od pomocy międzynarodowych instytucji finansowych, które udzielając jej, stawiają swoje warunki, stosunek tych instytucji do powiązań między środowiskiem naturalnym a gospodarką przenosi się na działania państw-pożyczkobiorców i ich podmiotów gospodarczych.

Celem niniejszego artykułu jest analiza i ocena stanowiska Międzynarodowego Funduszu Walutowego, prezentowanego w jego publikacjach, wobec koncepcji zrównoważonego rozwoju dążącej do pogodzenia niezbędnej redukcji eksploatacji środowiska z potrzebami społecznymi i gospodarczymi.

\section{ISTOTA KONCEPCJI ZRÓWNOWAŻONEGO ROZWOJU}

Już w latach 70. XX wieku wyraźnie dostrzegano wzajemne powiązania między środowiskiem naturalnym a społeczeństwem i gospodarką w ujęciu międzygeneracyjnym. Jest to dobrze widoczne w raportach Rady Zarządzającej Programu Środowiskowego ONZ (UNEP) z lat 1973-1976 (UNEP 1973-1976). W tym okresie dominowało jednak podejście ekorozwojowe, czyli aspekty społeczne i ekonomiczne były oceniane głównie z punktu widzenia środowiska, a pozostałe powiązania w tym trójkącie schodziły na dalszy plan. Wynikało to z ówczesnej popularności koncepcji ekorozwoju, czyli rozwoju zgodnego z potencjałem środowiska wykorzystywanego w trakcie tego rozwoju w sposób odpowiedni i racjonalny (Glossary of Environment Statistics 1997). Ekorozwój w klasycznym ujęciu stawiał jednak ochronę środowiska naturalnego w uprzywilejowanej pozycji względem innych aspektów życia społecznego i gospodarczego.

Dopiero Raport Światowej Komisji do spraw Środowiska i Rozwoju z 1987 roku, zwany Raportem Brundtland od nazwiska przewodniczącej Komisji, rozpropagował pojęcie sustainable development, łączące w sobie aspekty środowiskowe, społeczne i ekonomiczne jako równoprawne i współzależne. Angielskie słowo sustainable jest przeważnie tłumaczone na język polski jako „zrównowa- 
żony", choć w tym kontekście chodzi przede wszystkim o zdolność do kontynuacji, podtrzymywania, o trwałość jakiegoś stanu lub działania. Zrównoważenie w dosłownym znaczeniu jest tylko ubocznym aspektem w niektórych sferach sustainable development. Choć w roli polskiego odpowiednika trafniejsze byłoby używanie określenia trwały, ewentualnie trwały i zrównoważony, bądź nawet sustensywny rozwój, to jednak ze względu na jego popularność i obecność w krajowych regulacjach prawnych, od Konstytucji RP poczynając, w niniejszym artykule jako odpowiednik terminu sustainable development będzie stosowany zwrot „zrównoważony rozwój”.

Sformułowano dotąd ponad 100 definicji zrównoważonego rozwoju, jednakże najistotniejszą rolę w praktyce odgrywa definicja ze wspomnianego Raportu Brundtland: Zrównoważony rozwój to rozwój, który wychodzi naprzeciw potrzebom współczesnych pokoleń bez stwarzania zagrożenia dla zdolności do zaspokojenia ich przez przyszłe pokolenia (Brundtland 1987: 41, poz. 1). W tym Raporcie zawarto wiele założeń zrównoważonego rozwoju, mogących również stanowić punkt odniesienia dla oceny działalności Międzynarodowego Funduszu Walutowego (MFW), a przede wszystkim:

1. Zrównoważony rozwój jest daleki od wymogu zarzucenia wzrostu gospodarczego, a problemy biedy i niedorozwoju można rozwiązać przez nową erę wzrostu, w której kraje rozwijające się odegrają wiodącą rolę i zostaną dopuszczone do należnych im znaczących korzyści (Brundtland 1987: 39, poz. 49).

2. Nie istnieje jedna uniwersalna strategia zrównoważenia, ponieważ systemy gospodarcze i społeczne oraz warunki ekologiczne w poszczególnych krajach różnią się znacząco. Każdy naród będzie musiał rozwiązywać problemy konsekwencji swoich konkretnych polityk. Jednak, niezależnie od tych zróżnicowań, zrównoważony rozwój powinien być postrzegany jako cel globalny (Brundtland 1987: 39, poz. 51).

3. Żaden kraj nie może rozwijać się w izolacji od pozostałych. Realizacja zrównoważonego rozwoju wymaga zatem nowej orientacji w relacjach międzynarodowych. Długoterminowy zrównoważony wzrost będzie wymagał daleko idących zmian w przepływach produkcji, handlu, kapitału i technologii, które staną się bardziej sprawiedliwe i lepiej zsynchronizowane z wymogami środowiskowymi (Brundtland 1987: 39, poz. 52).

Ostatnie dwa punkty wskazują na to, że już ćwierć wieku temu wyraźnie dostrzegano ograniczenia powszechności i jakości zrównoważonego rozwoju, wynikające z braku odpowiedniego globalnego ładu gospodarczego i finansowego. 
Jednakże zawarta w punkcie pierwszym akceptacja wzrostu gospodarczego jako narzędzia likwidacji biedy i niedorozwoju stała się przyczyną znaczącej krytyki zrównoważonego rozwoju w ujęciu Raportu Brundtland (Kośmicki 2010: 114). Krytyka ta wynika z faktu, że jest to sformułowanie skwapliwie wykorzystane przez wiele organizacji tzw. consensusu waszyngtońskiego, z MFW na czele (Kośmicki 2010: 28), w sposób pomijający podkreślone silnie w tym Raporcie środowiskowe wymogi wobec wzrostu gospodarczego akceptowalnego w świetle koncepcji zrównoważonego rozwoju.

Sprzeczność między gloryfikowaniem bezwarunkowego wzrostu gospodarczego i wiązaniem go z koncepcją zrównoważonego rozwoju odnosi się chociażby do rosnącej w skali globalnej eksploatacji zasobów naturalnych (zwłaszcza nieodnawialnych - kopalin) mających zaspokoić potrzeby tego wzrostu. Postęp techniczny okazuje się niewystarczający, by temu przeciwdziałać, zwłaszcza przy szybko zwiększającej się liczbie ludności świata. W efekcie tej sytuacji, nawet przy zamrożeniu poziomu zużycia zasobów per capita, wolumen zużytych zasobów będzie rósł.

Niezależnie od różnic co do roli wzrostu gospodarczego, wszystkie ujęcia zrównoważonego rozwoju doceniają wpływ wzajemnych powiązań między wszystkimi poziomami zorganizowania społeczeństw (czyli lokalnym, regionalnym, państwowym i międzynarodowym) na możliwości utrzymania harmonii między ładami środowiskowym, społecznym i gospodarczym.

W niniejszym artykule, zgodnie z jego tematem, wyeksponowano poziom międzynarodowy od strony światowego ładu finansowego. Wsparciem w tym zakresie dla koncepcji zrównoważonego rozwoju jest koncepcja global governance, postulująca stworzenie reguł światowego kierowania (ale nie światowego rządu), porządkującego relacje międzynarodowe w sposób bardziej demokratyczny i wielostronnie korzystny niż obecnie (Kośmicki 2005: 152). To zagadnienie zostanie rozwinięte w części czwartej poświęconej ocenie funkcjonowania MFW w świetle koncepcji zrównoważonego rozwoju.

\section{STATUTOWY CEL DZiAŁANIA MFW}

MFW został powołany w 1944 roku jako element wspierający System z Bretton Woods, którego istotą była światowa hegemonia dolara USA dzięki jego wymienialności na złoto w transakcjach między Systemem Rezerwy Federalnej Stanów Zjednoczonych a innymi bankami centralnymi krajów członkowskich Systemu oraz utrzymywanie stałych kursów walutowych między walutami 
należącymi do Systemu, początkowo w bardzo wąskim paśmie wahań $+-1 \%$. $\mathrm{Z}$ owej istoty Systemu wynikała potrzeba powołania MFW jako instytucji stabilizującej swoimi pożyczkami rozliczenia między państwami członkowskimi, zwłaszcza w związku z saldami ich bilansów płatniczych.

Istotne jest to, że gdy w latach 1944-1971 funkcjonowała wymienialność dolara USA na złoto $w$ ramach reżimu kursowego, wiodący cel działania MFW był klarowny - utrzymanie sprawnego działania całego systemu walutowego. Wszelkie szczegółowe kompetencje MFW były temu celowi podporządkowane. Wraz z zawieszeniem wymienialności w 1971 roku, a następnie ostatecznym rozwiązaniem Systemu z Bretton Woods w 1973 roku MFW powinien był zostać zlikwidowany, ale przetrwał, przekształcając jedynie swoje priorytety i środki działalności (Friedman 1998). 0 ile za czasów funkcjonowania Systemu z Bretton Woods w działalności MFW dominowały funkcje regulacyjna oraz konsultacyjna, o tyle po jego rozpadzie zaczęły rozrastać się funkcja kredytowa i związana z nią funkcja kontrolna.

Po polsku przyjęło się nazywać tę instytucję Międzynarodowym Funduszem Walutowym, jednakże w jego oficjalnej angielskojęzycznej nazwie, International Monetary Fund, jest użyte określenie monetarny czy też pieniężny, a nie walutowy. Współcześnie, zgodnie z oryginalną nazwą, działalność MFW jest bardziej pieniężna w tym sensie, że udzielane przez MFW pożyczki w większości przypadków nie mają bezpośredniego związku ze sprawami walutowymi czy z bilansem płatniczym i łączą się z głęboką ingerencją w całe finanse i gospodarkę danego kraju-pożyczkobiorcy.

Obecne oficjalne cele działalności MFW nie odzwierciedlają zwrotu dokonanego w jego rzeczywistym funkcjonowaniu. Ten katalog celów obejmuje (IMF 2011: 2):

1. „Promowanie międzynarodowej współpracy pieniężnej za pośrednictwem stałej instytucji, która stanowi aparat służący konsultacjom i współpracy w międzynarodowych kwestiach pieniężnych".

Zgodnie z tym celem, MFW to przede wszystkim forum konsultacji i współpracy międzynarodowej, co nie uzasadnia jego dominującej w ostatnich dwóch dekadach roli prokuratora, sędziego i komornika oskarżającego, osądzającego i egzekwującego od różnych państw kształtowanie ich finansów i gospodarki według narzuconego przez MFW modelu.

2. „Wspieranie ekspansji i zrównoważonego wzrostu handlu międzynarodowego oraz przyczynianie się $w$ ten sposób do pobudzania i utrzymywania wysokich poziomów zatrudnienia i realnego dochodu oraz do 
rozwijania zasobów produkcyjnych wszystkich członków jako zasadniczych celów polityki gospodarczej".

W ramach tego celu istotną rolę odgrywa przywiązanie do paradygmatu wzrostu gospodarczego (rozwijanie zasobów produkcyjnych), ale zarazem ma on sygnalizować pewną wrażliwość społeczną MFW (utrzymywanie wysokiego zatrudnienia i dochodu). Jednocześnie jest to jedyny cel pozwalający powiązać jego działalność z koncepcją zrównoważonego rozwoju, choć w wariancie słabej trwałości ze względu na podkreślenie rozwoju zasobów produkcyjnych i brak odniesienia do środowiska naturalnego.

Pozostałe podane poniżej cele odzwierciedlają pierwotne zadania MFW z czasów funkcjonowania w ramach Systemu z Bretton Woods i odnoszą się do kwestii walutowych, bilansów płatniczych oraz rozliczeń międzynarodowych:

3. „Promowanie stabilności walutowej, utrzymywanie uporządkowanych relacji walutowych między członkami oraz unikanie konkurowania za pomocą deprecjacji walut".

4. „Pomoc w tworzeniu wielostronnego systemu płatności w odniesieniu do bieżących transakcji między członkami oraz w eliminowaniu ograniczeń walutowych, które utrudniają wzrost światowego handlu".

5. „Dawanie członkom poczucia bezpieczeństwa przez czasowe udostępnianie im podstawowych zasobów Funduszu pod warunkiem odpowiednich zabezpieczeń i stworzenie im w ten sposób możliwości skorygowania niedostosowań w ich bilansach płatniczych bez uciekania się do metod szkodliwych dla krajowego lub międzynarodowego dobrobytu".

Cel piąty jest jednak zarazem traktatową podstawą, chociaż bardzo wątłą, do rozbudowanej obecnie działalności pożyczkowej MFW, powiązanej z narzucaniem krajom-pożyczkobiorcom układanych przez niego programów restrukturyzacyjnych, które mają odgrywać rolę wspomnianych zabezpieczeń zwrotu udostępnionych przez MFW zasobów. Warto zwrócić uwagę, że działalność pożyczkowa MFW jest wymieniona dopiero jako piąty i przedostatni cel.

6. „Zgodnie z powyższym, skrócenie okresu i zmniejszenie poziomu nierównowagi w bilansach płatniczych członków. Fundusz powinien kierować się we wszystkich swoich politykach i decyzjach celami sformułowanymi w niniejszym artykule".

To końcowe zdanie tym mocniej podkreśla rozbieżności między obecnym sformułowaniem katalogu celów działania MFW a jego praktyką. 
W tym miejscu wykazano jedynie rozbieżność między traktatowymi a faktycznymi celami i metodami działalności MFW oraz ukazano nikłe powiązanie tak ujętych celów z głównym nurtem koncepcji zrównoważonego rozwoju, do której MFW chętnie się odwołuje.

Odniesienia do zrównoważonego rozwoju w publikacjach dotyczących faktycznej działalności MFW zostaną przedstawione w części trzeciej, a ocenie wkładu MFW w zrównoważony rozwój będzie poświęcona część czwarta artykułu.

\section{ODNIESIENIA DO ZRÓWNOWAŻONEGO ROZWOJU W PUBLIKACJACH MFW}

Specyfiką międzynarodowych instytucji finansowych, takich jak MFW czy Bank Światowy, jest z pozoru działalność mocno ograniczona do transakcji finansowych. Jednakże, mimo pewnych różnic związanych ze szczegółowym charakterem działania, obie instytucje mają potencjalne możliwości silnego oddziaływania na wiele dziedzin życia w krajach korzystających z ich funduszy. Co charakterystyczne, większe znaczenie i zarazem silniejsze skutki ma współpraca z tymi instytucjami dla krajów słabiej rozwiniętych, o mniejszej samodzielności finansowej i większych zagrożeniach dla ich zrównoważonego rozwoju.

MFW ma świadomość zbieżności między charakterystyką dominującej grupy swoich klientów a problemami zharmonizowania ładów środowiskowego, społecznego i gospodarczego zgodnie z paradygmatem koncepcji zrównoważonego rozwoju. Odwołania do koncepcji sustainable development można znaleźć w treści ponad 1200 pozycji znajdujących się w bazie publikacji MFW. $\mathrm{Z}$ drugiej strony, tylko kilka z nich odwołuje się w tytule do tej koncepcji, choć nie wszystkie mają treść bezpośrednio jej poświęconą.

Ostatecznie, tylko dwie publikacje MFW można uznać za w dużej mierze poświęcone zrównoważonemu rozwojowi. Pierwsza to 40-stronicowy zeszyt z 2002 roku, w którym omówiono fiskalne wymiary zrównoważonego rozwoju (Gupta i in. 2002). Drugą jest liczący prawie 300 stron raport z 2008 roku rozpatrujący wybrane aspekty zrównoważonego rozwoju na tle powiązań Milenijnych Celów Rozwoju z problemami środowiska (The World Bank), jednakże jest to publikacja wydana przez Bank Światowy, w której przygotowaniu pomagali pracownicy MFW.

Wśród publikacji MFW można znaleźć liczne odniesienia do związków między finansami i środowiskiem naturalnym, czego aktualnymi przykładami z 2012 roku mogą być: przewodnik dla decydentów, wskazujący, jak polityką fi- 
skalną ograniczać zmiany klimatyczne (de Mooij, Parry, Keen 2012), oraz artykuł o finansowaniu inwestycji w proekologiczne technologie (Eyraud, Clements 2012). Również ład społeczny w kontekście finansowym znajduje odzwierciedlenie w opracowaniach MFW, jak choćby w serii raportów o strategii redukowania biedy w poszczególnych krajach, np. raporty opublikowane w 2012 roku dotyczące Bangladeszu (IMF 2012a), Gwinei (IMF 2012b) i Laosu (IMF 2012c). Co ciekawe, niektóre raporty zostały przygotowane przez władze danego kraju pod kuratelą MFW i przy współpracy z innymi organizacjami międzynarodowymi (np. o Bangladeszu i Gwinei), a inne są raportami pracowników MFW (np. o Laosie).

W świetle dostępnych publikacji MFW można stwierdzić, że na poziomie werbalnym instytucja ta akceptuje koncepcję zrównoważonego rozwoju jako zestaw celów do osiągnięcia, jednakże pojawiają się wątpliwości co do szerszej akceptacji założeń tej koncepcji przez MFW.

\section{OCENA STOSUNKU MFW DO ZRÓWNOWAŻONEGO ROZWOJU}

Zasadniczym obszarem rozbieżności między głównym nurtem koncepcji zrównoważonego rozwoju a jej ujęciem w wersji MFW jest stosunek do standardowo ujmowanego wzrostu gospodarczego. W literaturze dotyczącej zrównoważonego rozwoju dominuje krytyka wzrostu gospodarczego jako polityczno-gospodarczego celu działania (Rogall 2010: 28). Zarazem pojawiają się propozycje akceptacji jedynie „zazielenionego” wzrostu gospodarczego, spełniającego ostre kryteria ekologiczne i społeczne, co wiąże się z zupełnie odmiennym od standardowego sposobem definiowania i kalkulowania wzrostu gospodarczego (Borys 2007: 280). Generalnie, wzrost gospodarczy na pewno nie jest traktowany w koncepcji zrównoważonego rozwoju jako podstawowe narzędzie osiągania jej celów. Zakłada się w niej konieczność wzrostu produktywności zasobów większego niż wzrost PKB oraz, niejako w konsekwencji, wzrost jakości życia zamiast wzrostu dochodów w krajach przemysłowych [m945, 2.08], gdyż inaczej eksploatacja środowiska naturalnego przekroczy bezpieczne granice.

Dokładnie odwrotnie wzrost gospodarczy jest oceniany z perspektywy MFW. Przykładowo, w opracowaniu o roli polityki fiskalnej w zrównoważonym rozwoju (Gupta i in. 2002: 2) podkreśla się wyniki badań sugerujących, że klasyczny wzrost gospodarczy w przynajmniej 90\% przypadków, gdy kraj osiągał wzrost co najmniej $2 \%$, przynosił poprawę sytuacji najuboższych. Ma to oznaczać, że inwestowanie w przyspieszanie standardowego wzrostu go- 
spodarczego jest najlepszym sposobem rozwiązania podstawowych problemów w ramach społecznego ładu zrównoważonego rozwoju. Brakuje przy tym odniesienia do problemu zmienności gospodarki rynkowej, która przez to nie wykazuje zdolności do utrzymania stałego i stabilnego wzrostu gospodarczego, co rzutuje również na niestabilność sytuacji najuboższych.

W swych opracowaniach MFW nie rozpisuje się o (przynajmniej krótkoi średnioterminowym) konflikcie między poziomem standardowego wzrostu gospodarczego a znacznymi nakładami proekologicznymi w połączeniu z ograniczeniami eksploatacji zasobów środowiska, które według koncepcji zrównoważonego rozwoju są tym bardziej konieczne, im bardziej spóźnione.

MFW eksponuje związek między polityką fiskalną a zrównoważonym rozwojem (Gupta i in. 2002: 3-5), ale podkreśla stanowczo, że odbywa się to przez służebną rolę polityki fiskalnej wobec wzrostu gospodarczego. Oznacza to jednak intensyfikację eksploatacji środowiska i jego zasobów w połączeniu z ograniczeniem bezpośredniego społecznego wymiaru polityki fiskalnej. Takie podejście stwarza istotne niebezpieczeństwo załamania się całego modelu, gdy wzrost gospodarczy napotka poważne bariery w danym kraju lub grupie krajów (choćby z powodu wahań cen surowców czy, jak obecnie, kryzysu finansowego). Trudno uznać za zgodne z koncepcją zrównoważonego rozwoju wyraźne przedkładanie funkcji alokacyjnej finansów publicznych nie tylko nad funkcję redystrybucyjną, ale także nad powiązaną z nią w pewnym zakresie funkcję stabilizacyjną.

Stanowisko MFW w sprawie zrównoważonego rozwoju można również ocenić na podstawie przemówienia jego prezesa, Christine Lagarde, wygłoszonego w kontekście Konferencji Narodów Zjednoczonych w sprawie Zrównoważonego Rozwoju (Lagarde 2012), która odbyła się w dniach 20-22 czerwca 2012 roku w Rio de Janeiro - co ciekawe, nie w jej ramach, a na forum The Center for Global Development w Waszyngtonie. 0 ile akceptowalne z punktu widzenia głównego nurtu zrównoważonego rozwoju są spostrzeżenia o obecnym potrójnym światowym kryzysie - gospodarczym, środowiskowym i społecznym - a także o znaczeniu stabilności makroekonomicznej i finansowej, o tyle charakterystyczne dla instytucji „consensusu waszyngtońskiego” silne podkreślanie roli przyspieszenia wzrostu gospodarczego budzi zastrzeżenia. Stwierdzenie, że wzrost gospodarczy potrzebuje stabilności, nie wymaga oceny z punktu widzenia zrównoważonego rozwoju, jednakże opinia, że tylko przy wzroście gospodarczym możliwa jest stabilność, koliduje z założeniami zrównoważonego rozwoju, zwłaszcza gdy w roli głównego motoru napędowe- 
go wyjścia ze wspomnianego potrójnego kryzysu jest prezentowane pobudzanie popytu.

Co ważne, zwiększeniu popytu ma być silnie podporządkowana dostosowawcza (accommodative) polityka pieniężna, użycie publicznych środków do bezpośredniego wsparcia banków oraz, gdy tylko fiskalnie możliwa, przyjazna wzrostowi (,growth friendly”) polityka. Jednocześnie, ma temu towarzyszyć wdrażanie średniookresowych planów redukcji długu publicznego, traktowanych jako instrument stabilizacji fiskalnej, w połączeniu z reformami w sektorach nierynkowych (czyli głównie w sektorze publicznym) oraz na rynku pracy w sposób zwiększający zatrudnienie wśród najmłodszych i najstarszych pracobiorców.

Powyższe i uzupełniające opinie mają stanowić argumenty za zwiększeniem zasobów finansowych MFW przeznaczonych na preferencyjne pożyczki, co prezes Lagarde uważa za jeden ze swoich priorytetów.

Analiza przedstawionych założeń popytowej recepty MFW na wyjście z obecnego kryzysu i kontynuowanie zrównoważonego rozwoju budzi istotne wątpliwości. Dla wielu krajów, nie tylko z Unii Europejskiej, założenia te oznaczałyby połączenie luźnej, proinflacyjnej polityki pieniężnej (wysoka podaż pieniądza, niskie stopy procentowe) z wysokimi wydatkami publicznymi na wszelkie możliwe działania pobudzające popyt i wzrost gospodarczy, na redukcję zadłużenia publicznego (zwłaszcza wobec zagranicy), na dokapitalizowanie banków pieniędzmi podatników oraz na reformę sektora publicznego i rynku pracy. Trudno w takiej sytuacji oczekiwać znaczących nakładów na ochronę środowiska i bieżące przeciwdziałanie ubóstwu, zarówno ze strony sektora publicznego, jak i prywatnego. Najbardziej prawdopodobnym efektem takiego zestawu działań będzie konieczność skorzystania ze wsparcia finansowego z MFW, co, jak wskazano powyżej, władze tej instytucji przewidują. Ponieważ MFW udziela pożyczek, stawiając krajom je zaciągającym warunek przestrzegania sformułowanych przez siebie zaleceń, tą drogą instytucja ta może wzmocnić swoją pozycję swoistego „rządu światowego”.

Jak wspomniano w części pierwszej, z koncepcją zrównoważonego rozwoju wiąże się idea światowego kierowania (global governance), z założenia sprzeczna z pomysłem światowego rządu, zwłaszcza z MFW w tej roli. Global governance ma nawiązywać do kantowskiej idei federacji światowej z koniecznym minimum centralnej władzy państwowej (Kośmicki 2005: 152), czemu najlepiej z obecnie istniejących instytucji może służyć Organizacja Narodów Zjednoczonych (Kośmicki 2010: 16). Oznacza to rearanżację światowego ukła- 
du polityczno-gospodarczego w kierunku wielostronnej współpracy (multilateralizmu) w miejsce dotychczasowej dominacji polityczno-gospodarczej jednego kraju (unilateralizm USA), za której strażnika jest uważany właśnie MFW.

\section{ZAKOŃCZENIE}

Zdaniem autora, o instrumentalnym podejściu MFW do koncepcji zrównoważonego rozwoju świadczą nie tylko poglądy zawarte w prezentowanych publikacjach, ale również kwestie, których się w nich nie porusza. MFW jako instytucja pieniężna o globalnym oddziaływaniu, nie tylko z nazwy, pomija sprawę systemowej reformy współczesnego światowego ładu pieniężnego, co świadczy o założeniu, że generalnie ład ten nie jest źródłem obecnych problemów globalnych. Praktycznie ignorowane przez MFW sprawy, takie jak skutki funkcjonowania pieniądza fiducjarnego, czyli pozbawionego kotwicy wartości, oraz pełnienia przez fiducjarnego dolara funkcji waluty światowej, zwłaszcza w rozliczeniach surowcowych, a także destabilizująca gospodarki działalność wielkich banków i kapitału spekulacyjnego, niewątpliwie zasługują na wnikliwą analizę z punktu widzenia perspektyw zrównoważonego rozwoju, a nawet wręcz jej wymagają.

Każde z wymienionych zagadnień ma istotne, a przy tym złożone konsekwencje ekonomiczne zarówno dla poszczególnych gospodarek krajowych, jak i światowego ładu gospodarczego, przez co nie sposób przedstawić ich kompleksowo w tym artykule. Warto jednak na koniec zasygnalizować narastający obecnie problem roli dolara jako waluty światowej w związku z rosnącym zagrożeniem tzw. wojnami walutowymi (precyzyjniej byłoby je nazwać walutowymi wojnami deprecjacyjnymi). Stany Zjednoczone intensywnie wykorzystują osłabianie kursu dolara wobec innych walut jako kluczowe narzędzie swej polityki antykryzysowej, zwiększając podaż dolara oraz utrzymując bardzo niskie stopy procentowe. Prowokuje to wiele krajów, jak choćby Japonię, Koreę Południową czy Brazylię, do ratowania konkurencyjności cenowej ich eksportu i hamowania napływu zagranicznych kapitałów spekulacyjnych za pomocą osłabiania kursu swoich walut względem dolara. Narastająca w efekcie globalna niestabilność kursowa stanowi zagrożenie dla ekonomicznego ładu w ramach zrównoważonego rozwoju, co siłą rzeczy wpływa również na ład społeczny.

Jeżeli Międzynarodowy Fundusz Walutowy poważnie traktuje koncepcję zrównoważonego rozwoju, to w świetle przytoczonych wyżej jego statuto- 
wych celów działalności powinien odgrywać rolę wiodącego animatora działań odsuwających groźbę wojen walutowych, zamiast zbywać temat wypowiedziami swojej szefowej, jak miało to miejsce na szczycie G-20 w Moskwie 16 lutego 2013 roku (IMF 2013).

\section{IIITERATURA}

Borys T. (2007), W poszukiwaniu syntetycznego wskaźnika zrównoważonego rozwoju, [w:] Obszary badań nad trwałym i zrównoważonym rozwojem, B. Poskrobko (red.), Wydawnictwo Ekonomia i Środowisko, Białystok.

Brundtland G. H. (1987), Report of the World Commission on Environment and Development: Our Common Future, United Nations, New York.

Eyraud L., Clements B. (2012), Going Green, Finance \& Development, vol. 49, no. 2.

Friedman M. (1998), Exchange Rate Regimes and East Asia, Project Syndicate, 7.10.1998, http://www.project-syndicate.org/commentary/exchange-rate-regimes-and-east-asia (dostęp: 13.11.2012).

Glossary of Environment Statistics (1997), Studies in Methods, Series F, no. 67, United Nations, New York.

Gupta S., Keen M., Clements B., Fletcher K., de Mello L., Mani M. (2002), Fiscal Dimensions of Sustainable Development, Pamphlet Series, no. 54, August 2002, International Monetary Fund, Washington D.C.

IMF (2011), Articles of Agreement of the International Monetary Fund, International Monetary Fund, Washington D.C.

IMF (2012a), Bangladesh: Poverty Reduction Strategy Paper, IMF Country Report no. 12/293, International Monetary Fund, Washington D.C.

IMF (2012b), Guinea: Poverty Reduction Strategy Paper, IMF Country Report no. 12/296, International Monetary Fund, Washington D.C.

IMF (2012c), Lao: Poverty Reduction Strategy Paper, IMF Country Report no. 12/286, International Monetary Fund, Washington D.C.

IMF (2013), Statement by IMF Managing Director Christine Lagarde on G-20 Ministerial Meeting in Moscow, Press Release no. 13/53, February 16, 2013.

Kośmicki E. (2005), Dylematy zrównoważonego rozwoju w warunkach globalizacji gospodarki, [w:] Zrównoważony rozwój. Od utopii do praw człowieka, A. Papuziński (red.), Oficyna Wydawnicza Branta, Bydgoszcz.

Kośmicki E. (2010), Zrównoważony rozwój w warunkach globalizacji gospodarki, Wydawnictwo Ekonomia i Środowisko, Białystok-Poznań.

Lagarde Ch. (2012), Back to Rio - the Road to a Sustainable Economic Future, International Monetary Fund, Washington DC, http://www.imf.org/external/np/speeches/2012/061212.htm (dostęp: 18.11.2012).

de Mooij R., Parry I. W. H., Keen M. (2012), Fiscal Policy to Mitigate Climate Change, A Guide for Policymakers, Pre-Publication Copy, International Monetary Fund, Washington D.C. 
Rogall H. (2010), Ekonomia zrównoważonego rozwoju - potrzeba reformy tradycyjnej ekonomii, [w:] Edukacja dla zrównoważonego rozwoju, t. 2: Edukacja dla ładu ekonomicznego, B. Poskrobko (red.), Wydawnictwo Ekonomia i Środowisko, BiałystokWrocław.

UNEP (1973-1976), United Nations Environment Programme, Report of the Governing Council, United Nations, New York.

The World Bank (2008), Global Monitoring Report 2008: Agenda for Inclusive and Sustainable Development MDGs and the Environment, The International Bank for Reconstruction and Development/The World Bank, Washington D.C. 
